\title{
Machiavelli's Passions
}

\author{
Matteo Faini* \\ Max Weber Fellow, European University Institute, Florence
}

Niccolò Machiavelli looks at us with an ironic smile. He escapes us, deceives us and at times even mocks us: "For some time now, I never say what I think, nor do I think what I say, and even if I tell the truth sometimes, I hide it among so many lies, that it's hard to find it again."1 That ironic smile hides a tragic figure. Usually well hidden, it reveals itself in the moments of deepest desperation. "So if I sometimes laugh or sing, /", he wrote soon after being tortured and imprisoned, "I do it because I have just this one/ Way of giving vent to my bitter cry."2 I want to uncover what lies at the heart of this tragedy using Machiavelli's own interpretative technique. Uncovering a complex, at times deceitful figure is a problem that Machiavelli himself faced repeatedly in his years as Florentine Secretary. Whether it was Cesare Borgia or Caterina Sforza, Machiavelli had to interpret the gestures and words of statesmen that were masters of deception. The strategy he developed to uncover these statesmen's intentions was based on the analysis of human passions, on uncovering the fundamental trait that defined a man's character.

I apply Machiavelli's strategy of interpretation to Machiavelli himself. I do so by relying extensively on his letters and his comedies. Machiavelli would have envied the wide access that we have to the most private works of our subject of study. Had he had access to similarly private works by Cesare Borgia, his job as the Florentine envoy would have been much easier. Through this work of interpretation of human passions, I will uncover the irreconcilable disconnect which shapes Machiavelli's tragedy. On one hand, he relates to his objects of desire by entirely abandoning himself to them, regardless of how unachievable they are. On the other, to obtain these objects of desire his analytical mind develops strategies which take pride in their adherence to what he called the "effectual truth of the matter."3 His incapacity to reconsider his objectives in light of the means at his disposal and his tendency to transfer all of himself into his objectives determined Machiavelli's successes and failures. He repeatedly failed when he had to set his own goals, or when he approached a problem with empathy. He succeeded when he was given precise and limited objectives and when he understood that he did not share the goals of those he was studying.

The next section discusses how other scholars have struggled to understand the fundamental disconnect at the heart of Machiavelli's tragedy, focusing on the final exhortation of The Prince. The third section describes Machiavelli's interpretative strategy. The fourth section applies this strategy to his personal writings in order to understand what passions animated him, and then uses these passions to interpret some famous passages of The Prince. The fifth section looks at his political successes and failures and explains them in light of this fundamental disconnect between goals and means. The final section asks whether Machiavelli was aware of this fundamental disconnect. Looking at his comedies and at his epistolary exchanges with Francesco Guicciardini, I conclude that he was ironically self-aware.

\section{How could a realist embrace such unrealistic goals?}

Machiavelli most famously embraced an unrealistic goal in the concluding exhortation of The Prince. This was far from being the only time he did so, but by focusing on the interpretations of The Prince's twenty-sixth chapter I can review the literature relating to my central problem. After being kicked out of power, exiled and tortured by the Medici, why was Machiavelli appealing to the Medici themselves to liberate Italy from the barbarians? Did he think that such an enterprise was feasible? If so, why did he reach a conclusion which, by virtually all accounts, was utterly implausible?

We can identify three ways in which readers of Machiavelli have reacted to this puzzle. First, many scholars simply ignored the final chapter of The Prince. As early as 1523 the Aristotelian Agostino Nifo published De Regnandi Peritia, a heavily plagiarized version of the still unpublished The Prince. Nifo transformed The Prince into a scientific treatise on all forms of government. In such a scientific treatise, there was no space for an exhortation to liberate Italy from the barbarians. The final chapter was thus excluded from Nifo's plagiarised work. ${ }^{4}$ Those who, like Nifo, interpreted Machiavelli as the founder of a neutral science of politics, could not explain why The Prince ends the way it does. For instance, the German scholar Hermann Conring, who

\footnotetext{
* faini.matteo@gmail.com
} 
published a Latin translation of The Prince in 1660, believed that the exhortation bordered on ridicule and was "out of place in the science of principality." 5

Second, the oblique interpretation of The Prince, possibly the most frequent one throughout history, argues that the final exhortation should not be taken literally and does not convey what Machiavelli actually believed. In Rousseau's words, The Prince was "a book for republicans", a satire that ridiculed princes and put on display their evils and hypocrisies. The final exhortation was thus a trap for the Medici, to encourage them to embark on an overly ambitious enterprise which would have caused their ruin. ${ }^{6}$ Two centuries after Rousseau, Leo Strauss proposed a different but equally oblique interpretation. The concluding exhortation of The Prince was an attempt to justify Machiavelli's attack on biblical morality and on religion in general by giving it the honorable goal of liberating Italy. ${ }^{7}$ Strauss writes: "Machiavelli does not merely suppress mention of the unholy means which are required for the achievement of the sacred end. He surreptitiously introduces a new end [liberating Italy], an end not warranted by the argument of the first twenty-five chapters. [...] He thus creates the impression of that all the terrible rules and counsels given throughout the work were given exclusively for the sake of the common good." 8 The last chapter is thus a fig leaf which Machiavelli tried to use to give a noble touch to his evil teachings. Machiavelli himself "did not regard the practical proposal with which he concluded The Prince as practicable. He had measured the forces of contemporary Italy too well to have any delusions." What I intend to show is that Machiavelli was all too full of these "delusions."

The interpretation of The Prince as a satire was fatally weakened by the publication in 1810 of Machiavelli's famous letter to Vettori of 10 December 1513, announcing the composition of The Prince. The letter showed that Machiavelli hoped that The Prince would have helped him obtain some form of employment from the Medici, for whom he was willing to perform even the most menial of tasks, such as "rolling over a stone." 10 The publisher of the letter, the Bolognese professor Angelo Ridolfi, reinterpreted The Prince in a way in which most scholars today would agree with. The Prince was the work of a Republican, who believed that Italy needed a new Prince. ${ }^{11}$ Machiavelli's intention was expressed passionately and sincerely in the final exhortation. His goal was to liberate Italy and the Medici family was the only one who could do so. ${ }^{12}$ Obtaining this goal, Ridolfi continued, seemed not just plausible but probable. With the Medici ruling over Rome and Florence, circumstances were favorable for the liberation of Italy. ${ }^{13}$ Ridolfi interpreted The Prince as the work of a patriot, whose goal was to liberate and unify Italy in order to enable his fatherland to compete with the other nation-states of Europe.

Machiavelli was indeed a patriot who loved his fatherland more than his soul, ${ }^{14}$ but did he truly believe that the political and military conditions for the liberation of Italy existed in 1513 ? If so, why did he reach such an unrealistic conclusion? The defenders of the oblique interpretation were quick to point out this weakness in the patriotic interpretation, although they could not restore their own preferred one. Twice the Italian Romantic poet Ugo Foscolo picked up his pen and tried to critique Ridolfi's work, defending the interpretation of The Prince as a satire. Both times Foscolo had to give up, abandoning his essays half way. What Foscolo did point out was that the conditions for the unification of Italy in 1513 simply did not exist. The Italian states "were not strong enough to invade one another nor weak enough to be invaded by one another." Had the Medici attempted to unify all of Italy, "all the Italian states would have opposed themselves with all their strengths, forming an alliance to maintain their liberty." 15 Unable to solve this puzzle, Machiavellian studies reached a dead end. The question of whether Machiavelli had really believed in the liberation of Italy by the Medici or whether he intended to cause their ruin was, in the words of the editors of his works in 1813, "a secret buried in his soul, which we don't have the presumption to uncover." 16

In the past century scholars such as Rudolf von Albertini and Felix Gilbert have addressed this puzzle in a novel way. Rather than viewing it as a contradiction that needed to be resolved, they argued that the contradiction was inherent in Machiavelli himself. Albertini argued that "Machiavelli experiences, in all of its tragedy, a profound contrast. He sees the internal and external political crisis, he analyzes it and harshly criticizes the weaknesses and the mistakes of Italy and of Florence; but he constantly forces himself not to give up arms, no matter how bleak the situation. [...] If he at times has reason to despair of Florence and of Italy, he always finds enough strength to believe."17 "Well aware of the difficulties", Albertini continues, "Machiavelli himself doubts of the possibility of enacting such a proposal; he asks himself if his proposal is not just a chimera or an unachievable ideal. [...] Yet he cannot give up, despite all his doubts, the ideal of renewal. [...] From this point of view we can see in Machiavelli an idealist or even a romantic." ${ }^{18}$ Most recently, Maurizio Viroli has reinterpreted The Prince as an oration that ends with an exhortation for one individual to redeem Italy from its ills. Machiavelli passionately believed it was possible to redeem his fatherland. He was in fact a strange realist, one inclined to imagine orders that no one had ever given and who fought tenaciously to realize them. ${ }^{19}$ 
This article builds on these works, reading Machiavelli using his own interpretive technique. In this sense, I follow in Strauss's footsteps when he warned us to read Machiavelli the way he read others. Unlike Strauss, however, my reading of Machiavelli is not based upon just a few passages of The Prince and the Discourses ${ }^{20}$ but upon the entirety of his works and upon the technique which Machiavelli himself developed through "a long experience of modern things and a continuous learning from ancient ones". ${ }^{21}$ Although Machiavelli meant the Discourses and The Prince to include everything he knew, this does not mean that they should "be read each by itself without any reference whatever to anything outside them." 22 When an interpretation is controversial, it is a needless self-inflicted mutilation to rely only on a subsection of Machiavelli's works.

\section{Machiavelli and the Interpretation of Reality}

After spending fourteen years trying to interpret the gestures and words of at times inscrutable princes, Machiavelli knew that political reality is hard to grasp. Yet he never abandoned the conviction that we can understand reality, if tentatively and partially. Machiavelli's own works would not make sense if he did not believe this to be the case.

Two main obstacles complicate any understanding of political actions. ${ }^{23}$ First, political actors shroud their plans in secrecy. Machiavelli first learned this in his formative missions to Cesare Borgia. ${ }^{24}$ Borgia was so secretive that what he was going to do was known only to himself. No matter how skillfully Machiavelli tried to "enter under" him, Borgia always managed to keep Machiavelli at a distance. ${ }^{25}$ A secretive prince keeps both his adversaries and his subjects guessing as to what his next moves are going to be. He thus builds a reputation for himself that awes his subjects and keeps them at bay. ${ }^{26}$ Second, statesmen always present their intentions in the most favorable light. No matter how ill-intentioned, Cesare Borgia declared that he wished nothing but Florence's friendship and alliance.

The way to overcome these obstacles is found in the eighteenth chapter of The Prince. "In general, men judge more by their eyes than by their hands; because everyone gets to see, but few get to feel. Everyone sees what you seem, few feel what you are." ${ }^{27}$ To understand what a prince really is and to go beyond mere appearances, we have to judge by the hands, not by the eyes. The expression "judging by the hands" refers to a tale narrated by both Luigi Pulci and Poggio Bracciolini, in which a young thrush sees tears in the eyes of a man who is killing his cage mates. The thrush infers that the man will have compassion on the other birds, but an older bird admonishes him to look at the hands and not at the eyes, that is, at what the man does rather than at what he says (or seems to be saying). ${ }^{28} \mathrm{~A}$ correct judgment cannot be based solely on what we see, because appearances are deceptive. We should instead "feel" [sentire] the political actors that are in front of us. What we find once we go beyond appearances and "get under" the men we are trying to interpret are what Machiavelli variously described as a man's passions, his character, his fantasies, his way of proceeding or his nature. Feeling means understanding the fundamental trait that characterizes each man, shapes his actions and dominates his mind.

Machiavelli began to develop this method of interpreting reality before The Prince and continued to use it until late in his life. In 1503, in Del modo di trattare i popoli della Valdichiana, Machiavelli argued that human beings as a whole have always had the same passions, but these passions are distributed differently among each individual. ${ }^{29}$ In the Ghiribizzo al Soderini in 1506, Machiavelli stated that nature has "made men with diverse wit [ingegno] and diverse fantasy [fantasia]" and "successful [felice] is he who matches [riscontra] his way of proceeding with the times. [...] However, because times and circumstances change frequently [...], whereas men do not change their fantasies nor the ways of proceeding, it happens that a man is successful in one time, and unsuccessful in another." ${ }^{30}$ Understanding a man's character is thus essential, both because it is constant and because, based on the riscontro with the times, it allows us to predict whether or not a man will succeed.

We see this method of interpreting reality most clearly at work in Machiavelli's letter to Vettori on 26 August 1513. He describes "the state of the world's affairs" [stato delle cose del mondo] based on the character and passions of princes and peoples:

we have a pope who is wise, and thus serious and cautious; an unstable and fickle emperor; a king of France who is disdainful and timid; a stingy and avaricious king of Spain, a king of England who is rich, fiery and hungry for glory; the Swiss who are brutal triumphant and insolent; we here in Italy are poor ambitious and cowardly. ${ }^{31}$ 
Knowing the passions of rulers and people, Machiavelli believes, is the way to get to know the state of the world. We may not be able to predict specific courses of action once we know what passions animate a certain ruler, but we will be among the few that move beyond appearances and reach the effectual truth of the matter.

Machiavelli continued to use this method of interpreting reality throughout his lifetime. For instance, when instructing the young Raffaele Girolami on his ambassadorial trip to Spain in 1522, Machiavelli's first suggestion was that to succeed in his task, an ambassador has "to know well the nature of the prince and of those who govern him", meaning those who counsel him and shape his choices. More specifically, in meeting the Emperor Charles V, Raffaele Girolami had to "observe the nature of the man, if he governs by himself or lets himself be governed, if he is stingy or spendthrift, if he loves peace or war, if glory moves him or another passion $[\ldots] .{ }^{332}$

Machiavelli's method of interpretation was the one that most Florentines adopted in his time. As Felix Gilbert argued, "it seemed to the Florentines [...] that all [great states'] actions were determined by the arbitrary will of the ruler. Consequently, whenever discussion in the pratiche [assemblies] turned to the questions involving these great states, a kind of psychological guessing game developed about the personal qualities and inclinations of their rulers." 33

One's own passions, however, can get in the way of analysis. Machiavelli was aware of this possibility, and he told Vettori as much on 10 August 1513. The two had disagreed over the desirability of French control of Northern Italy, with Machiavelli in favor of it and Vettori against it. Rather than attributing this to mere differences in opinion, Machiavelli argued that their differences had "a similar foundation of natural inclination or passion [naturale affectione o passione]." ${ }^{34}$ Machiavelli was accusing Vettori of being deceived by his passions, an accusation that Vettori vigorously rejected in his next letter: "you seem to fear that a natural inclination or passion can deceive either you or me. To this I respond that I have no inclination whatsoever for the anti-French party, nor any strong passion that moves me [in these matters]. ${ }^{35}$ Vettori may well have turned this accusation against the accuser himself. As I will show, Machiavelli's passions repeatedly led him to believe things that, even without the benefit of hindsight, should have seemed utterly implausible. ${ }^{36}$

\section{A passionate strategist}

What were Machiavelli's passions, or character? How can we uncover them and what can we understand by looking at them? Before answering these questions, I must deal with two possible objections. First, some may wonder whether it makes sense to apply Machiavelli's own strategy of interpretation. Machiavelli repeatedly reached unrealistic conclusions by applying this strategy to the problems of his own times. Regardless of how insightful we find Machiavelli's political works to be, he was often wide of the mark when judging contemporary affairs. Why, then, use a strategy that has a poor record of success? I am not, however, employing it to understand any historical event or figure, but the person who devised this strategy of interpretation in the first place. If, as Najemy argues, Machiavelli often projected his personality and passions onto the historical figures he studied, the strategy he devised to understand them may tell us a lot about Machiavelli himself. ${ }^{37}$ In other words, if Machiavelli's strategy of interpretation had poor results because Machiavelli was attributing his own passions to the figures he studied, it should have better results in analyzing Machiavelli himself.

A second objection concerns the use of his personal letters to uncover these passions. A recurring topos in humanist letter writing was the rejection of the responsibility of authorship. A tradition dating back to Cicero held that letters were written with the first words that came to mind, often in a disorderly way. Further, the character, style and subject of the letter was determined by the intended recipient, and not by the author. Petrarch, for instance, argued that by adapting himself to his recipients, he was forced to be very inconsistent in his letter writing, to the point of differing from himself. ${ }^{38}$ However, it is unclear if Machiavelli really wrote his letters with the first words that came to mind. For some letters we possess both a draft and a final version, hardly evidence of hasty writing. In any case, even if Machiavelli wrote the first things that came to his mind, this would strengthen my case for using his letters to uncover his passions. It is when our writing is more spontaneous that our passions are freer to rise to the surface. Furthermore, the notion that an author had to be inconsistent in order to adapt to his recipients was always more fictional than real. Petrarch himself, who argued this most forcefully, noted that the letters are a sort of record, or reflection, of one's own psychological and stylistic history, that taken individually they are about his correspondents, but taken together they are about him. ${ }^{39}$

Many scholars have read Machiavelli's letters on love and his comedies in light of The Prince. They have thus noted that the principles that govern action in love are the same that govern action in politics. Hanna Pitkin, for instance, observes that "the rules of conduct for private life displayed in Machiavelli's fiction and 
letters are much the same as those advanced for public life in his political theory." ${ }^{40}$ Any reader of the Mandragola will recognize that the deviousness and calculating mind of Ligurio, who organizes a clever plot to trick the beautiful Lucrezia into sleeping with his friend Callimaco, resemble the foxy qualities of the Machiavellian prince. ${ }^{41}$ Similarly, Machiavelli's skepticism concerning men's claims to act according to high moral principles is evident in The Prince as well as in his comedies and letters.

Whereas these readings are fairly common, far fewer scholars have read The Prince in the light of Machiavelli's letters and comedies. Once we do so a less obvious similarity emerges. Once we "get under" Machiavelli to "feel" what he is really like, we find a deeply passionate man who relates to his objectives by abandoning himself to them, whether liberating Italy from the barbarians or conquering the love of his latest flame.

Niccolò knew how merciless his passions could be, and in what was perhaps his deepest moment of desperation he tried to eliminate them altogether. "I've resolved myself not to desire anything with passion", he wrote to Francesco Vettori on 9 April 1513. "From now on, do not bother much of all the things that I may ask from you, because even if I don't obtain them, I won't be passionate about them." ${ }^{2}$ Those were the words of a man who had lost nearly everything he cared about. His life as Secretary of the Florentine Republic had ended abruptly in November the year before. He had been accused of being part of an anti-Medicean conspiracy, tortured, condemned to remain within Florentine territory and forbidden from entering Palazzo Vecchio, the palace of the government around which all of his life had rotated until then.

In his darkest moments Machiavelli understood that the fastest cure to his many ills was to amputate his passions. And yet, despite everything he had suffered, Machiavelli probably knew all along that this attempt at self-mutilation was doomed to fail. Less than three weeks later, his passions were again fully on display. In a letter on 21 April 1513, Vettori asked for Niccolò's judgment on a recently signed truce between France and Spain, adding that "I have found it [your judgment] in these matters more solid than that of any other man with whom I've spoken." ${ }^{43}$ Machiavelli accepted Vettori's invitation with the greatest enthusiasm: "Reading [your letter], and I read it repeatedly, I always forgot my unhappy situation, and it seems to me to have returned to those dealings in which in vain I endured many hardships and spent much time." ${ }^{44}$ Perhaps sensing how excessive this enthusiasm was, and how much it contrasted with the sobering tone of what he had written only three weeks before, Machiavelli decided to leave this passage out of the final draft of the letter he sent to Vettori on 29 April. ${ }^{45} \mathrm{He}$ knew that his passions were again getting the better of him, and he did not want his friend to know.

On other occasions he did not refrain from revealing his passions to others. His letters on love provide us with the clearest examples. On 18 January 1514, Vettori turned again to Machiavelli for advice. It was not King Ferdinand who was keeping him awake this time, but the beautiful and young Costantia. "I have almost become a prisoner of this Costantia", Vettori reveals. "Before, at times a woman would come and at times another, and I didn't feel passionate about any of them [...] but when Costantia came closer to me, I liked her so much that I cannot think of anyone but her; and because I've seen you in love sometimes and I understand how passionate you were, I resist as much as I can. I don't know if I will be strong enough, but I doubt it." ${ }^{\prime 6}$ Vettori's words echo Machiavelli's words of less than a year before. Just like his friend, the Florentine ambassador to the Holy See was trying to resist his passions. Machiavelli at this point knew how vain this was and without hesitation told him how he had governed himself when dealing with Love's powerful arrows:

I let him [Love] do as he pleased and I followed him through valleys, woods, cliffs, and fields, and I have found that he has caressed me more than if I had tormented him. Take off then [...] and say: Go ahead, Love, guide me and lead me yourself: if I come out well, may praise be yours; if badly, yours the blame: I am your slave. ${ }^{47}$

John Najemy has interpreted this passage as a self-parody of The Prince. Machiavelli is giving Vettori the opposite advice that he had given to princes. Princes had to control Fortune and preserve their autonomy, whereas Vettori should relinquish all attempts at control and give in himself entirely to Love. Only by doing so will he be able to limit Love's ability to harm him. ${ }^{48}$ There may indeed be an element of self-parody here, but there is a more important similarity. We find in this exhortation to let oneself be carried away by Love's force the same passionate abandonment that Italians will feel for their Redeemer, allowing him to liberate Italy from the barbarians.$^{49}$ If Love carried Machiavelli through valleys, woods and cliffs, the Love that the Italians will feel for their Redeemer will similarly accompany him across all provinces [Né posso esprimere con quale amore e' fussi ricevuto in tutte quelle provincie], with all doors open to him [Quali porte se li serrabbano?] and all people obedient to him [Quali populi li negherebbano la obedienzia? ${ }^{50}$. 
This abandonment to love is reaffirmed in the next exchange of letters. Machiavelli's inspired lines were not enough to convince Vettori. It wasn't the supposed prestige of his ambassadorial post that was holding Vettori back. Rather, he was reluctant to spend what he should have given to his daughters and he believed it was vile to let his voluptuousness get the better of him. For two days, he stayed firm in his intention to remove Costantia from his soul altogether. The third day, Costantia's mother visited Vettori accompanied by her daughter, and Vettori could not resist. ${ }^{51}$ For those who consider Machiavelli the heartless father of Realpolitik, loving a young woman at the cost of jeopardizing the prestige of one's State should have been unacceptable. On the contrary, Machiavelli once again advised his friend to "follow love unbridled" [seguitiate l'amore totis habenis] and begged him to "follow your star, without letting any parts of it go for anything in the world, because I believe, have believed and will always believe that it is true what Boccaccio says: that it is better to do and regret, than not to do and regret." 52

Although Machiavelli formulates it while speaking of love, the reach of Boccaccio's maxim extends to Machiavelli's vision of politics. ${ }^{53}$ This maxim is hardly one that a prudent, calculating and, one may say, Machiavellian statesman should embrace. A prudent statesman should set realistic goals, carefully calculate the risks involved in any course of action and choose the one which allows him to obtain his goals at minimum costs, if any exist. Machiavelli failed at the very first step. As we shall see, the goals he set were invariably overly ambitious.

Machiavelli's idealism was deeply Florentine. As Gilbert says, "there sometimes appears, in these deliberations [on foreign policy] of men who prided themselves of having the most subtle minds of Italy, an unrealistic, illusionary spirit. In their inner hearts, the Florentines would never believe that their situation could ever be hopeless." ${ }^{54}$ This idealistic element existed side by side with the better known aspects of Machiavelli's realism: adhering to the effectual truth of the matter in order to be politically effective, judging political leaders based on the results of their actions, and the necessity for any State to have a strong military power. ${ }^{55}$ How did Machiavelli reconcile his adherence to the effectual truth of the matter with his passionate abandonment to his goals?

Once we have set a goal that is overly ambitious, no realistic analysis can tell us how to obtain it. At this point a realist statesman would reconsider his objectives and set the bar lower. Machiavelli, however, twisted reality to make it more accommodating to his own goals. In truly idealistic fashion, he solved the irresolvable tension between his goals and his analysis of reality by claiming that success goes to those who are willing to act impetuously, challenging the odds. "Fortune is a woman," he tells us in chapter 25 of The Prince, "and wanting to subdue her it is necessary to beat her and hit her." Thus, in accordance with his own interpretive strategy, Machiavelli understands the apparently inexplicable "great variation of reality" 56 by giving a nature and a passion to that variation. Fortune can be understood because she is a woman. As such, she lets herself be won by those who beat her and hurt her, and "she is a friend of the young, because they are less cautious, more courageous and they command her with greater audacity." 57

This passage symbolizes the victory of the idealist element over the realist one. By resorting to this metaphor Machiavelli was hardly adhering to "the effectual truth of the matter" he claimed to pursue in chapter 15. He does not tell us that Fortune is a woman to illustrate and explain a logical argument. Instead, the metaphor substitutes for an argument that is nowhere to be found, because it would have been logically untenable. When faced with the unsolvable disjunction between goals and means, Machiavelli resorted to mythology and even invoked God's friendship for those who were courageous enough to pursue great and just endeavors ${ }^{58}$. Machiavelli was not willing to allow the effectual truth of the matter to get in the way of his final exhortation to liberate Italy.

In another famous passage in The Prince Machiavelli tries to defend his tendency to set overly ambitious goals as prudence. In chapter 6 Machiavelli tells us that:

a prudent man should always follow the footsteps of great men, and imitate those who have been the most excellent, so that if his virtue does not equal theirs, at least it will savor of it; [He should do] like prudent archers, who, having to hit a target far away, and knowing how far their arch can shoot, take aim above their target, not in order to reach so high with their arrow, but to be able to obtain their goal with the help of such a high aim. ${ }^{59}$

Machiavelli was trying here to reconcile his adherence to the effectual truth with his tendency to set overly ambitious goals, by saying that it is prudent to aim for targets that we know are too high. He does not deal, however, with an obvious objection, namely that by aiming too high we could end up obtaining nothing at all. 
Perhaps aware of this objection, Machiavelli gradually removes prudence from the scene. Tellingly, in chapter 25 prudence is never mentioned, and praise is reserved for boldness and audacity.

\section{Successes and Failures of a Too Passionate Strategist}

If Machiavelli had the tendency to set himself goals that were too ambitious and passionately abandon himself to them, we should observe that his actions and his analyses were more successful and more accurate when he was working with limited goals set by someone else. We might expect to see him failing when he was setting the goals himself, or when he was attributing to other actors goals which arose from his own passions. I will now look briefly at two of Machiavelli's most important successes and failures, and show that they correspond to this pattern.

\section{The Militia, the conquest of Pisa and the sack of Prato}

The creation of the militia was Machiavelli's most grandiose project in his years as Secretary of the Florentine Republic. In 1505, after having failed three times in the previous ten years to conquer the rebel Pisa, the head of the Florentine government, the gonfaloniere Pier Soderini, approved Machiavelli's idea of raising a militia ${ }^{60}$ As I will illustrate, the militia initially proved effective, contributing to the conquest of Pisa in 1509, but collapsed in 1512 during its first serious encounter with the battle-hardened Spanish troops, leading to the downfall of the Florentine Republic and of its Secretary. Machiavelli's desire to follow the Roman exemplum in creating the militia contributed to the militia's most glaring flaws, possibly dooming the entire project.

Machiavelli never mentioned the Roman exemplum in his contemporary writings advocating for the militia, ${ }^{61}$ whereas his later works, especially The Art of War, explicitly use the Roman model to defend the militia. As Mikael Hörnqvist has persuasively argued, Machiavelli avoided citing the Roman exemplum because it was highly controversial among the Florentine optimati, whose skepticism towards the militia Machiavelli needed to overcome. Nonetheless, the Roman model profoundly shaped Machiavelli's conception of the militia, from its basic structure to the choice of its commanders. ${ }^{62}$ After being reproached for having referred to the Romans when suggesting how to deal with the rebellious Valdichiana in 1503, Machiavelli explicitly avoided doing so in 1506, telling Giovan Battista Soderini that "it is not common [non si usa] to refer to the Romans." 63

Ironically, even though Florentine aristocrats such as Piero Guicciardini rejected Roman references out of hand, Machiavelli did not have to deviate from the Roman exemplum to overcome the optimati's opposition to the militia. The optimati's greatest fear was that the militia would have become an instrument of tyranny in the hands of the Gonfaloniere or of military commanders with bonds of loyalty to their troops that were stronger than those between Florence and the troops themselves. To prevent this, Machiavelli's militia was not a permanent force, but one made up of peasants who would go back to their occupation immediately after the war was over. They would have met once a month in groups of 150-300 men to practice together and every member had to practice on his own every Sunday. In order to avoid the creation of pernicious personal loyalties, its leaders could not stay with their unit for more than six months and could not exercise their command in their place of origin or where they owned significant property.

Machiavelli would have developed the militia along similar lines, even without the optimati's skepticism. Studying Roman history, Machiavelli had come to oppose the creation of both a permanent military force and of long-standing loyalties between troops and their commanders. As he later argued in the Discourses, a crucial cause of the enslavement of the Roman Republic was the repeated prolongation of the power of military commanders. Fewer men became commanders, thus forming a dangerous military aristocracy, and those few were able to forge a bond of loyalty with their troops which they then used for their own partisan goals. ${ }^{64} \mathrm{He}$ opposed permanent military forces because, as he later argued in Book I of The Art of War, war is an art which does not allow men to live honestly, and those who make war their art will be rapacious, fraudulent and violent. The decline of the Roman Republic began when its citizens stopped seeing their military duties as a temporary service to the Republic, and some started to see warfare as a permanent career from which they could gain personal advantage. ${ }^{65}$ Again following the Roman exemplum, the militia's backbone was the infantry, whereas cavalry played only a secondary role. ${ }^{66}$ The recruitment of cavalrymen began only in 1511 , shortly before the whole project was destroyed by the fall of the Florentine Republic. ${ }^{67}$

By rotating commanders so frequently, Machiavelli prevented the creation of those personal bonds between soldiers and their leader which are so important in motivating and disciplining the troops. Machiavelli repeatedly emphasized the importance of discipline, yet he did not seem to realize that in order to create admiration for a leader, which he himself deemed necessary for discipline, he had to keep commanders with their units for longer periods of time. Further, by training together only once a month, and in groups that were 
too small to practice the infantry square, the Florentine militia could not acquire the skills and coordination that would have been necessary to face the battle-hardened armies then fighting across Europe. ${ }^{68}$ The militia's biggest flaws, and the ones that ultimately proved fatal, could thus be directly attributed to Machiavelli's desire to follow the Roman exemplum.

Despite all these defects, the militia succeeded in its first important operation. On 4 June 1509, Pisa surrendered to Machiavelli himself. ${ }^{69}$ The militia did not prove decisive, however. During the siege it had been used to devastate the countryside and block the opponent's sorties. Sensing its defects, the Florentine government, despite Machiavelli's insistence, decided not to use it to assault the walls after a breach. ${ }^{70}$ The militia could not have competed with the Swiss pikemen and their offensive capabilities, yet it proved effective and disciplined in the limited tasks which were assigned to it. Florence's final assault never occurred. Lacking support from Venice, which had just been defeated by France and Spain at the battle of Agnadello, as well as from France and Spain themselves, whose neutrality Florence had bought at a high price, Pisa had no choice but to surrender. ${ }^{71}$ With a clear and limited objective, namely the conquest of Pisa, Machiavelli obtained his greatest success. Tellingly, however, the Florentine government had to intervene to rein in his ambitions and his tendency to overreach. Left to his own devices, we can only speculate what Machiavelli would have tried to do with his militia, and how the militia would have performed.

Three years later, the government's lack of confidence in the militia proved to be well founded. In just a few months, the great French victory in the battle of Ravenna on 11 April 1512 turned into a nightmare for the traditionally pro-French Florentine Republic. French troops rushed back home after the battle, leaving their Florentine allies at the mercy of the remaining Spanish and Papal troops. Cardinal Giovanni de' Medici, later Pope Leo X, seized the opportunity to finally get rid of the despised Florentine Republic, reinstating the rule of his own family. On 30 August 1512, 6,000 Spanish troops attacked the Florentine-controlled Prato. Defending Prato were 2,000 militiamen raised by Machiavelli. As soon as the Spaniards breached the walls, the militiamen ran away, vainly looking first for an escape and then for pity. Florence panicked as soon as it received news of the massacre. Despite having 16,000 militiamen ready for war, the Florentines were not willing to fight. A group of young Mediceans forced their way into Palazzo Vecchio and compelled the Gonfaloniere Pier Soderini to leave. The Florentine Republic was dead, abandoned at the moment of truth by those who were supposed to defend her. ${ }^{72}$

Machiavelli's militia had collapsed in its first serious encounter with the enemy. In its moment of truth, the militia displayed an utter lack of discipline and cohesion. Both defects were a consequence of Machiavelli's admiration for the Roman exemplum. Niccolò had aimed too high. His arrow pointed at a too distant target, and ended hitting none at all.

\section{Machiavelli's Memorandum to Leo X in December 1514}

On 3 December 1514 Francesco Vettori wrote to Machiavelli asking for his advice on Pope Leo X's foreign policy. The Pope's goal, Vettori told Machiavelli, was to maintain the Church's prestige and territory, and soon increase the latter. The French King, who had recently allied with the English King, was about to launch an operation to recover Milan from the Swiss, with the help of the Venetians. The Emperor, Spain and the Swiss were united in their defense of Milan. On whose side, Vettori asked Machiavelli, should the Pope be, if any? Will the alliance between France and England last? Vettori told Machiavelli to write his memorandum assuming that the Pope himself would read it. ${ }^{73}$

In just a few days Machiavelli completed the memorandum, with an enthusiasm that is easy to imagine. The memorandum is a combination of highly insightful analyses and grossly overstated ones. Whenever Machiavelli identified with a certain figure or country, his realism abandoned him. The first part of the memorandum is Machiavelli at his best. He starts by calculating how strong each side was. France and England could field an army of 20,000 men against the Swiss in Burgundy, a larger one against Milan and an even larger one in Navarre, while also deploying a strong fleet. The few and weak Venetian forces would not add much to this already powerful force. Machiavelli did not believe that the Anglo-French alliance would soon fall apart. The English King, Henry VIII, still resented the Spanish King over the unilateral truce Spain had signed with France the year before. The enmity between the French and English people was also not a factor, "because people want what their Kings want, and not vice-versa." He didn't believe that French conquests in Italy would worry [darli briga] Henry VIII to the point of breaking the alliance. Henry VIII would worry either out of envy or out of fear, but he had no reason to envy because he could cover himself with glory fighting in Spain, nor reasons to fear because conquering Milan would not have strengthened the French. With his forces fighting in Italy, the French King could not attack England, whereas he would have to fight the powerful Swiss for the control of untrustworthy Milan. If he managed to take control of Castile, instead, the English King 
would pose a much bigger threat to France. On the other side, the Swiss could field two armies of 20,000 men in Burgundy and Milan, whereas the combined forces of Spain, the Emperor and Milan would hardly surpass 15,000 men. In a long war, the French and English side would have won, because, having more money, they could keep their armies on the field for longer. ${ }^{74}$ If, instead, war soon came to a decisive battle, the Swiss and their allies had a better chance.

Up to this point, Machiavelli's analysis was impeccable: a clear net assessment of forces and an insightful look at the intra-alliance dynamics on the French side. From now on, however, Machiavelli's own passions gradually stepped in, and the analysis became increasingly unrealistic. If the war ended quickly with a decisive battle, Machiavelli continued, the French still had a chance. The French could send their fleet to Liguria or Tuscany and, as soon as they landed, Northern Italy would side with them, as would many others. Machiavelli assumed that popular uprisings would immediately follow the French landing, but he does not explain why. More importantly, Machiavelli seems to forget that he was writing to Pope Giovanni de' Medici who, as we have seen, had come back to power in Florence only two years before, overthrowing the popular-based Florentine Republic. The last thing the Pope wanted to happen were popular uprisings spreading throughout Italy. Yet, this is precisely what Machiavelli told him that he should promote. ${ }^{75}$

Machiavelli then argued that the Pope's best option was to side with the French, and field an army that would march through Tuscany with the French troops that had just landed, while uprisings spread throughout the country. Machiavelli's traditional pro-French sympathies may have a played a role here, although more important seems to have been his projection on the Pope of his own preference for more popular-based regimes. Machiavelli then asked himself whether the Pope should fear more the French or the Swiss, once one or the other had won with the Pope's support. His answer is categorical. The Pope should side with the French because:

if the Swiss conquered one Italian state, the liberty of Italy is over, as every day with a thousand pretexts, they will extract tribute, prey states and change governments [...]. They must be thinking about this, and even if they don't think of it, the order of things will make them think so, because conquest and victory create thirst for more of the same. [...] If they win, the Swiss will be soon giving laws to the Pope and to every other Italian prince. ${ }^{76}$

How could Machiavelli think that the Swiss, a loose confederacy of relatively few alpine pastors turned into pikemen, could dominate the whole Italian peninsula? The key is found two paragraphs later. The consequences of Swiss domination, Machiavelli tells us once more, would be "the servitude of the Pope and of all of Italy, without any hope of salvation, because the Swiss are an armed republic beyond comparison with any other prince or power." ${ }^{\prime 77}$ It is easy to see what led Machiavelli astray. The Swiss were an armed republic, just like the Romans, hence they must also soon expand and conquer their neighbors. As he had said to Vettori in a letter on 10 August 1513, the Swiss were first content with defending themselves, then they started making occasional raids, and finally, as they grew more courageous and powerful, they would have sought to dominate the whole peninsula. What sparked Machiavelli's fear of the Swiss was a comment that a Florentine envoy had overheard from them, while they were fighting with the French and the Florentines in 1500. As Machiavelli reports it, "the Swiss often reasoned among themselves about the virtue of their militia, of how similar it was to the Roman one, and that there was no reason they could not do as the Romans had done." $" 78$

Thus, once Machiavelli identified some similarities between the Swiss and the Romans, he inferred that the Swiss would have soon created their own empire. He could not conceive that the Swiss did not have the will, not to mention the capabilities, to build an empire. If the Swiss were not thinking about it yet, he wrote in the memorandum, they would do so soon. Machiavelli was projecting his own immoderate goals onto the subjects he studied. As soon as he identified the Swiss with the Romans, he empathized with them and attributed to them goals and capabilities that no analysis grounded in reality would have confirmed.

Machiavelli transferred all of himself into his objects of study, whether these were the Swiss or the ancient Romans. "Mi transferisco tucto in loro", he had said to Vettori on 10 December 1513. He was referring to the ancients and their histories, but his tendency to transfer all of himself went far beyond them.

\section{Conclusion: Tragedy and Self-Irony}

Machiavelli was aware of his tendency to set overly ambitious goals. His own tragic smile was the smile of a man who knew that his grandiose plans were destined to remain on paper. Impeded by what he called "the malignity of the times" from putting his ideas into practise, Machiavelli resorted to teaching his ideas to others, 
while laughing at his own misadventures ${ }^{79}$ His whole life was a constant struggle between the "effectual truth of the matter" and the great objectives he set for himself. We've seen in his letters, such as the one to Vettori on 9 April 1513, that he sensed how high a price he was paying to his passions, trying to delude himself about the possibility to eliminate them. We've seen how he tried to wrestle with the fundamental disjunction between goals and means throughout The Prince. Yet if we want to observe more clearly the self-ironic and tragic smile which arose from this disjunction, it is to his comedies that we have to turn, Mandragola and Clizia.

Long believed to have been written in 1518, recent scholarship has persuasively argued that Machiavelli wrote large parts of the Mandragola in 1513-1514. ${ }^{80}$ Roughly at the same time as he was writing the Prince, Machiavelli was also working on the story of a clever plot designed by Ligurio to trick the beautiful Lucrezia into sleeping with his friend Callimaco. As we have seen, Ligurio's cunning and foxy traits have long been associated with the Machiavellian prince, and rightly so. Less acknowledged, however, have been the Machiavellian traits in Callimaco, usually dismissed as a passive figure benefiting from Ligurio's ingeniousness ${ }^{81}$ Callimaco abandons himself to love just like Machiavelli. Callimaco's unfulfilled desire for Lucrezia leads him to stop sleeping, eating and taking pleasure in any activity whatsoever. ${ }^{82}$ Niccolò's love led him to stop enjoying "reading of ancient things, or reasoning about modern ones", ${ }^{83}$ what he had once called the "food that alone is mine and for which I was born." ${ }^{84}$ At the same time, Callimaco lucidly analyzes the obstacles he faces in his desperate attempt to conquer Lucrezia, just as Machiavelli would. Lucrezia's honest nature, her husband's wealth and her reserved life leave Callimaco hopeless: "What hope do you have?" asks his servant Siro. "Alas! None", replies Callimaco. Yet, Callimaco adds right afterwards, "nothing is so desperate that there isn't a way to find hope in it, and even though this way is fragile [debole] and uncertain [vaga], the will and the desire that a man has to obtain it makes it seem otherwise." 85 "It is necessary", he pleads Ligurio, "that I nourish myself with hope, if not a true one, at least a false one."

We can almost picture Machiavelli's tragic smile emerging on his face as he was writing these words. Here he was, as he would later write in the prologue, forced to show his virtue in deeds unworthy of a great man, mocking his own attempts at greatness. ${ }^{87} \mathrm{He}$ knew that he constantly pursued overambitious goals, yet he could not prevent himself from seeing hope where he knew there wasn't any. Machiavelli was just like his fellow Florentines, who would "never believe that their situation could ever be hopeless." 88

Machiavelli's other great comedy, Clizia, provides us with another example of ironic self-awareness. Written in 1524-1525, it portrays the competition between a father and a son for the young and beautiful Clizia. The father, Nicomaco, is an ironic self-representation of the old Machiavelli, from whom he even takes the name. Despite his old age and his lack of vigor, Nicomaco continues to abandon himself to love, letting his life and family go astray in pursuit of his love for Clizia. ${ }^{89}$ In a truly Machiavellian fashion, he devises a devious plan to get his faithful servant Pirro to marry Clizia, in order to then enjoy her company at will with Pirro's consent. When his plan seems to crumble in front of his wife's and his son's opposition, he resorts to the invocation of God and Fortune, just like the last two chapters of The Prince. ${ }^{90}$ Fortune initially seemed to smile upon him, despite her supposed preference for younger men. However, she soon turned her back on him, leaving him in bed with someone very different from the beautiful Clizia. Nicomaco makes a fool of himself with his relentless pursuit of his desire despite his old age. ${ }^{91}$ More than just an old lover, Machiavelli mocks his own incapacity to stop pursuing his own desires and objectives with the same intensity (albeit not the same vigor) of a young man.

Up until his very last days, Niccolò continued to pursue overly ambitious goals in the face of all odds. True to his own words and his own self, he continued to believe that to do and regret is better than not to do and regret. Just a year before passing away, again we find Machiavelli devising plans that were as grandiose as they were unrealistic. In a letter of May 1526 to Francesco Guicciardini, who five years before had gently reproached him for "having always been greatly extravagant in opinion and inventor of things new and unsual", ${ }^{92}$ Niccolò proposed to secretly strengthen the troops of Giovanni dalle Bande Nere against the invading imperial troops that will then go on to sack Rome. More than the specifics of the case, what interests us are the words with which he introduced such a proposal: "Let me say something that will seem crazy to you. I will propose a plan that you will consider either bold or ridiculous. Nonetheless, these times require audacious, unusual and strange decisions." 93

No matter how self-aware he was of his own vices, Niccolò was not going to change his nature. If, on his deathbed, someone had pointed these vices out to him, he may have replied with what his dear friend Vettori once told him in very different circumstances: "you should never reproach someone who knows he is mistaken; because by doing so, you will only increase his passions, and he won't retreat from his mistake." 94

\section{Notes}


1. Machiavelli's letter to Francesco Guicciardini on 17 May 1521. In Machiavelli, Lettere, 402-405. All translations are mine, except when noted.

2. Letter to Francesco Vettori on 16 April 1513. In Machiavelli, Lettere, 242-4.

3. The Prince, chapter 15.

4. Procacci, Machiavelli, 65-71; and Borrelli, “Agostino Nifo e il plagio del Principe”, 271-3.

5. Procacci, Machiavelli, 257-263.

6. Ibid. 347 and 370.

7. Strauss, Thoughts on Machiavelli, 55-6.

8. Ibid., 79.

9. Ibid., 72.

10. Machiavelli, Lettere, 305.

11. Ridolfi and Foscolo, Scritti sul Principe, 101-2.

12. Ibid., 119-120.

13. Ibid., 121.

14. See Machiavelli's letter to Vettori, 16 April 1527. In Machiavelli, Lettere, 504-505.

15. Ridolfi and Foscolo, Scritti sul Principe, 153-154.

16. Cited in Procacci, Machiavelli, 379.

17. Albertini, Firenze dalla repubblica al Principato, 60.

18. Ibid., 65-6.

19. Viroli, Redenzione dell'Italia, xiv-xvi and chapter 2.

20. The most famous of these passages is cited in Strauss Thoughts on Machiavelli, 30.

21. The Prince, Dedicatory letter.

22. Mansfield, Machiavelli's Virtue, 225. See also Strauss Thoughts on Machiavelli, 17.

23. Viroli, Machiavelli's Realism, 473-476.

24. Ridolfi, Vita di Niccolò Machiavelli, 75-80; and Viroli, Sorriso di Niccolò, chapters 6-7.

25. "[E]ntrare sotto" is the expression that Machiavelli uses to describe his attempts to unveil the intentions of the secretive Cesare Borgia while discussing with him on 7 October 1502, cit. Najemy, Between Friends, 66.

26. This is one of the three explanations that Machiavelli gives for Ferdinand of Aragon's behavior in his letter to

Vettori on 29 April 1513. See Machiavelli, Lettere, 257; and Najemy, Between Friends, 132-4.

27. The Prince, chapter18.

28. Bardazzi, Tecniche narrative, 1486-1487.

29. In Istorie Fiorentine e altre opere, 91-5. The same point was restated in Machiavelli, Discourses, Book III, chapter.43.

30. Machiavelli, Lettere, 228-231.

31. Machiavelli, Lettere, 291-6.

32. In Istorie Fiorentine e altre opere, 225-9.

33. Gilbert, Machiavelli and Guicciardini, 32.

34. Machiavelli, Lettere, 275-281. As translated in Najemy, Between Friends, 152.

35. Machiavelli, Lettere, 282-290. As translated in Najemy, Between Friends, 153.

36. Ironically, in a letter to Vettori on 5 January 1514 he mocked two of their common friends writing that "it is a certainly a great thing to consider how blind people are in those things in which they sin, and what sharp persecutors they are of the vices they do not have." Here, instead, Machiavelli was accusing Vettori of a sin that he himself was most guilty of. See Machiavelli, Lettere, 313-314. The translation is in Najemy, Between Friends, 254.

37. Najemy, Between Friends, 134.

38. Ibidem, 27-9.

39. Ibidem, 29.

40. Pitkin, Fortune Is a Woman, 6.

41. Machiavelli, Opere, 697-770.

42. Machiavelli, Lettere, 239.

43. Vettori's letter to Machiavelli on 21 April 1509. Machiavelli, Lettere, 245-249.

44. Machiavelli's letter to Francesco Vettori on 29 April 1513. Machiavelli, Lettere, 250-258.

45. Najemy, Between Friends, 122-123.

46. Machiavelli, Lettere, 316-320.

47. Machiavelli's letter to Francesco Vettori on 4 February 1514. Machiavelli, Lettere, 320-323. As translated in Najemy. Between Friends, 268.

48. Najemy, Between Friends, 268.

49. For a similar point, see Viroli, Sorriso di Niccolò, ch. XVI.

50. All quotes are from The Prince, chapter 26.

51. Vettori's letter to Machiavelli on 9 February 1514. Machiavelli, Lettere, 324-326.

52. Machiavelli's letter to Vettori on 25 February 1513. Machiavelli, Lettere, 327-330. 
53. Cf. De Grazia, Machiavelli in Hell, 129.

54. Gilbert, Machiavelli and Guicciardini, 44.

55. Viroli, Machiavelli's Realism, 477.

56. The Prince, chapter 25.

57. Ibidem.

58. The Prince, chapter 26.

59. The Prince, chapter 6.

60. Viroli, Sorriso di Niccoló, 82-84.

61. Reproduced in Istorie Fiorentine e altre opere, 97-133. See especially the Discorso dell'ordinare lo Stato di Firenze alle armi or La cagione dell'Ordinanza, 99-104.

62. Hörnqvist, Perché non si usa allegare i Romani, 148-191.

63. Ibid., 166-170. See also Machiavelli, Lettere, 229.

64. See especially Machiavelli, Discourses, Book III, Chapter 24.

65. Machiavelli, Art of War, Book I, in Opere, 1256-1262.

66. Machiavelli, Discourses, Book II, Chapter 18: "How following the authority of the Romans and the example of the ancient militia, we should esteem infantry more than cavalry."

67. Pieri, Rinascimento, 438.

68. Pieri, Rinascimento, 438-442.

69. Viroli, Sorriso di Niccoló, ch.XI.

70. Pieri, Rinascimento, 442.

71. Pieri, Rinascimento, 442; and Pellegrini, Guerre d'Italia, 136-9.

72. Viroli, Sorriso di Niccoló, chapter13; Pieri, Rinascimento, 498-9; and Pellegrini, Guerre d'Italia, 135-9.

73. See Vettori's letter to Machiavelli on 3 December 1514 and Machiavelli's first and second replies on 10 and 20

December. Machiavelli, Lettere, 348-9, 351-361 and 363-7 respectively. See also Najemy, Between Friends, 295-310.

74. Cf. Machiavelli, Discourses, Book II, Chapter 10.

75. Najemy, Between Friends, 301.

76. Machiavelli's letter to Vettori, 10 December 1514, in Lettere, 351-361, quote on 356.

77. As translated in Najemy, Between Friends, 303. My emphasis.

78. Machiavelli's letter to Vettori on 10 August 1513. Machiavelli, Lettere, 275-281.

79. See Discourses, "Proemio" to Book II.

80. Stoppelli, Mandragola: storia e filologia, 69-89. I use Stoppelli's translation of the text.

81. A partial exception is Ruggiero, Machiavelli in Love, 147-152. Ruggiero notes that Callimaco resembles

Machiavelli in his way of abandoning himself to love and in his analysis of the obstacles he faces in conquering

Lucrezia. Ruggiero does not note, however, how Machiavellian he is in reconciling what is (or at least initially seems) irreconcilable.

82. Machiavelli, Mandragola, Act I, Scene 3 in Stoppelli, Mandragola: storia e filologia, 188.

83. Machiavelli's letter to Vettori, 3 August 1514 in Machiavelli, Lettere, 346-7.

84. Machiavelli's letter to Vettori, 10 December 1513. Machiavelli, Lettere, 301-6. For other similarities between the Mandragola and the epistolary exchanges with Vettori, see Stoppelli Mandragola: storia e filologia, 83-6.

85. Machiavelli, Mandragola, Act I, Scene 1, in Stoppelli Mandragola: storia e filologia, 181-2.

86. Machiavelli, Mandragola, Act I, Scene 3, in Stoppelli Mandragola: storia e filologia, 188.

87. Stoppelli, Mandragola: storia e filologia, 77 and 174.

88. Gilbert, Machiavelli and Guicciardini, 44.

89. Machiavelli, Clizia, Act II, Scene 4, 198-9.

90. Machiavelli, Clizia, Act III, Scene 6.

91. See the Canzona at the end of Act II in Clizia : "As much as love is beautiful in a young heart, so it is inconvenient in those whose spring has passed already."

92. Guicciardini's letter to Machiavelli on 18 May 1521. Machiavelli, Lettere, 407-8.

93. Machiavelli's letter to Guicciardini on 15 March 1526. Machiavelli, Lettere, 454-8.

94. Vettori's letter to Machiavelli on 9 February 1514. Machiavelli, Lettere,324-6.

\section{Bibliography}

Albertini, Rudolf von. Firenze dalla repubblica al Principato. Turin: Einaudi, 1970.

Bardazzi, Giovanni. "Tecniche narrative nel Machiavelli scrittore di lettere." Annali della Scuola Normale Superiore di Pisa 3, (1975): 1443-1489.

Borrelli, Gianfranco. "Agostino Nifo e il plagio del Principe" in Il Principe di Niccolò Machiavelli e il Suo Tempo. 1513-2013, edited by Alessandro Campi, 271-273. Rome: Treccani, 2013.

De Grazia, Sebastian. Machiavelli in Hell. Princeton: Princeton University Press, 1989.

Gilbert, Felix. Machiavelli and Guicciardini. Politics and History in Sixteenth-Century Florence. Princeton: Princeton University Press, 1965.

Hörnqvist, Mikael. "Perché non si usa allegare i Romani: Machiavelli and the Florentine Militia of 1506", Renaissance Quarterly, 55, (2002): 148-191. 
Machiavelli, Niccolò. Lettere. Edited by Franco Gaeta. Milan: Feltrinelli, 1961.

Machiavelli, Niccolò. Opere di Niccolò Machiavelli. Edited by Rinaldo Rinaldi. UTET, Turin, 1999.

Machiavelli, Niccolò. Istorie Fiorentine e altre opere storiche e politiche. Edited by Alessandro Montevecchi. Turin: UTET, 2007.

Machiavelli, Niccolò. Mandragola. Clizia. Edited by Ettore Mazzali. Rome: Feltrinelli, 2010.

Mansfield, Harvey C. Machiavelli's Virtue. Chicago: The University of Chicago Press, 1998.

Najemy, John. Between Friends: Discourse of Power and Desire in the Machiavelli-Vettori letters of 1513-1515. Princeton: Princeton University Press, 1993.

Pellegrini, Marco. Le guerre d'Italia 1494-1530. Bologna: il Mulino, 2009.

Pieri, Piero. Il Rinascimento e la Crisi Militare Italiana. Turin: Einaudi, 1952.

Pitkin, Hanna. Fortune Is a Woman: Gender and Politics in the Thought of Niccolò Machiavelli. Berkeley: University of California Press, 1984.

Procacci, Giuliano. Machiavelli nella Cultura Europea dell'Età Moderna. Rome: Laterza, 1995.

Ridolfi, Angelo and Ugo Foscolo. Scritti sul Principe di Niccolò Machiavelli. Edited by Paolo Carta, Christian Del Vento and Xavier Tablet. Rovereto: Nicolodi editore, 2004.

Ridolfi, Roberto. Vita di Niccolò Machiavelli. Florence: Sansoni Editore, 1972.

Ruggiero, Guido. Machiavelli in Love. Baltimore: Johns Hopkins University Press, 2007.

Stoppelli, Pasquale. La Mandragola: storia e filologia. Rome: Bulzoni Editore, 2005.

Strauss, Leo. Thoughts on Machiavelli. Chicago: The University of Chicago Press, 1958.

Viroli, Maurizio. Il Sorriso di Niccolò: Storia di Machiavelli. Rome: Laterza, 1998.

Viroli, Maurizio. "Machiavelli's Realism”, Constellations 14, (2007): 466-482.

Viroli, Maurizio. La redenzione dell'Italia. Saggio sul "Principe” di Machiavelli. Rome: Laterza, 2013. 